\title{
Refleksja nad lekturą książki pt. "Różnorodnośćkulturowa w opiece pielęgniarskiej” pod red. Joanny Zalewskiej-Puchały i Anny Majdy, Wyd. MOIPiP, Kraków 2014
}

\author{
Danuta Zarzycka
}

Katedra i Zakład Pielęgniarstwa Pediatrycznego, Wydział Nauk o Zdrowiu, Uniwersytet Medyczny w Lublinie

\author{
AUTOR DO KORESPONDENCJ: \\ Danuta Zarzycka \\ Katedra i Zakład Pielęgniarstwa Pediatrycznego, \\ Wydział Nauk o Zdrowiu \\ Uniwersytet Medyczny w Lublinie \\ ul. Chodźki 2, 20-093 Lublin \\ e-mail: danuta.zarzycka@umlub.pl
}

Kilka miesięcy temu (koniec 2014 rok) na półkę z moimi książkami trafiła monografia tematyczna poświęcona kulturowym aspektom opieki zdrowotnej. Pozycja o pokaźnej objętości 227 stron, w eleganckiej graficznie i starannej introligatorsko okładce wzbogaciła podręczny księgozbiór czekając na jej studiowanie.

Od kilku tygodni w opinii publicznej coraz częściej i dobitniej pojawiają się słowa polityków, którzy wskazują, że w ramach solidarności europejskiej Polska, jako jeden z krajów UE powinna przyjąć uchodźców z Afryki. Kolejne informacje to wyjazdy polskich służb, w tym medycznych do wielu krajów świata $\mathrm{z}$ misjami humanitarnymi, ostatnio do Nepalu.

Uświadomiłam sobie, że współzależność i integracja narodów to jest istniejąca rzeczywistość, globalizacja to nie tylko termin umieszczany na łamach artykułów, stronach większych opracowań, czy projektów badawczych.

Mimo iż, znane mi są założenia pielęgniarstwa transkulturowego M. Leininger, czy swoistość opieki uwzględniającej odrębności religijne, nie czułam się przygotowana do sprawowania opieki nad nowymi potencjalnymi pacjentami.

Szybko skierowałam wzrok w kierunku mojej półki z książkami, gdzie czekała wyżej wspomniana pozycja. Już zapoznając się ze spisem treści dostrzegłam, że Autorki monografii pochodzą z Krakowskiego ośrodka naukowego, dwie z nich ukończyły warsztaty wrażliwości kulturowej Akademii Treningu Antydyskryminacyjnego oraz wiele szkoleń dotyczących kompetencji kulturowych profesjonalistów medycznych, są ekspertkami w spotkaniach grup roboczych ds. sytuacji migrantów w polskiej ochronie zdrowia, więc z każdą chwilą wzrastała moja ciekawość poznawcza.

Celem opracowania, jak definiują same Redaktorki we wstępie (s. 8) jest: „ograniczenie poczucia frustracji w obliczu niespodziewanych $i$ trudnych do rozwikłania różnic kulturowych $i$ zapewnienie pewnego stopnia przewidywalności oczekiwań oraz zachowań pacjentów odmiennych kultur" czyli pozycja dla mnie, a może i wielu podobnych mi osób.

Układ pozycji jest pięcioczęściowy o wyraźnie najobszerniejszej ostatniej części, ale zaczynamy od początku, gdzie opisano różnice kulturowe w postrzeganiu człowieka i komunikowaniu się ludzi, uwzględniając badania i analizy kulturoznawców, psychologów, czy socjologów kultury. I nie jest to łatwy w odbiorze fragment treści monografii, ale podstawowy, a zatem konieczny, aby zrozumieć złożoność kultury, tożsamości kulturowej (płciowa, seksualna, grupy wiekowej, etniczna i rasowa, religijna, klasowa, narodowa, regionalna) i jej odrębności. Autorki sięgają po obrazowe słowne porównania najważniejszych terminów, na przykład pisząc o kulturze, jako rzeczywistości nakrytej przez „czapkę niewidkę”, którą każdy tworzy i jest jej odbiorcą, mając wpisany przez wieki kod kulturowy (s. 24).

Kolejny fragment to opis związku kultury i zdrowia, w którym Autorki posiłkują się teoriami D. Matsumoto i L. Juang oraz E.T. Halla, ale też wskazać należy, że nie jest to jedyny fragment opracowania, gdzie wyraźnie wskazano na teoretyczną interpretację rozważanego problemu, co stawia analizowaną pozycję wśród nielicznych, godnych polecenia, jako rzetelnie opracowany podręcznik akademicki.

Moją uwagę zwraca rozdział poświęcony stereotypom traktowanym, jako część natury człowieka, nad którą w relacji zawodowej musimy panować, ale wcześniej poznać jej mechanizm, w czym pomagają uporządkowanie tekstu poprzez zastosowanie kunktatorów i rycin.

$\mathrm{W}$ tym miejscu należy docenić, oprócz wartości merytorycznej również konwencję wypowiedzi, która wyraża się w personalnej, a nawet osobistej perspektywie doświadczenia Autorek i to w pierwszym rozdziale - punkcie wejścia w tematykę - odgrywa rolę pozytywną i stanowi zachęcający środek retoryczny wypowiedzi. 
Nie mogę pominąć z powodu atrakcyjności treści, rozdziału poświęconego komunikowaniu się $\mathrm{w}$ relacjach międzyludzkich, ale z uwzględnieniem swoistości kulturowej, gdzie wśród zachowań niewerbalnych czytam „mimika - np. szybkie uniesienie brwi dla Brytyjczyka oznacza sceptycyzm, dla Amerykanina zdziwienie, a Chińczyka - nie zgadam się z czymśs"(s.71). Zapoznając się z treściami poświęconymi regulacjom prawnym poświęconym imigrantom i uchodźcom oraz konsekwencjom imigracji i uchodźctwa w perspektywie jednostkowej i globalnej szybciutko podążam do rozdziału wyczekiwanego, czyli przedstawiającego odrębności w opiece zdrowotnej nad imigrantami i uchodźcami z Czeczenii, Białorusi, Afganistanu, Wietnamu, Ukrainy, Rosji i Indii. Charakterystyka opieki zdrowotnej względem każdej z wymienionych grup obejmuje/zawiera wizerunek $\mathrm{w}$ dyskursie politycznym, medialnym i społecznym, kulturę, tradycje i obyczaje, analizę kultury według R. Gestelanda oraz odmienności w opiece i komunikowaniu. Wśród problemów zdrowotnych uchodźców z Czeczenii po przyjeździe do Polski najczęściej występują u osób dorosłych: choroby somatyczne spowodowane użyciem broni chemicznej i biologicznej czasie pierwszej i drugiej wojny czeczeńskiej a dzieci najczęściej cierpią na nadpobudliwość psychoruchową (s.132-133)

Objętość kartek książki do przeczytania szybko się zmniejsza, wiem już, że Białorusini zachowują ośmiogodzinny post przed przyjęciem komunii świętej a sposobem okazywania szacunku dla pacjenta - Afgańczyka jest unikanie z nim kontaktu wzrokowego, gdyż tego nie lubią, czują się zawstydzeni i niepewni oraz wiele, wiele innych prawd kulturowych, których znajomość pozwoli zapewnić opiekę profesjonalną, a nie przypadkową o niskiej jakości. Lektura dobiega końca i chociaż w tym opracowaniu nie znalazłam odpowiedzi na pytanie o odrębności w problemach uchodźców z Afryki, to czuję się spokojniejsza, gdyż wiedza o kulturze i opisane analizy jej wpływu na opiekę zdrowotną pozwalają mieć większą perspektywę spojrzenia na innych przedstawicieli kultur nie tylko europejskich.
Zamknięcie przeczytanej książki nie pozwala pozostawić problemu, gdyż zastanawiam się nad tym, co powinniśmy zrobić w systemie kształcenia szeroko rozumianego personelu medycznego, czy w przyszłości wystarczy wiedza o odrębnościach kultury i opieki zdrowotnej potencjalnych pacjentów, czy może należy więcej czasu poświecić na kształtowanie wrażliwości kulturowej pielegniarek, położnych, lekarzy i innych grup zawodowych oraz umiejętności praktycznych w zastosowaniu jej w praktyce w kierunku wyzbycia się stereotypów kulturowych na rzecz opieki transkulturowej. Kompetencje kulturowe są wynikiem świadomego procesu ich kształtowania w ramach programów podstawowego kształcenia zawodowego, które pozwalają skutecznie funkcjonować w sytuacjach zawodowych w różnych kontekstach kulturowych, innych niż własnej kultury. W polskim pielęgniarstwie tylko elitarne ośrodki akademickie, wspomniany wcześniej Uniwersytet Jagielloński, Collegium Medicum w ramach zajęć obowiązkowych realizują program kształcenia w zakresie Komunikowanie międzykulturowe. Jest to przykład dobrej praktyki i inicjatywy związanej $\mathrm{z}$ ochroną zdrowia migrantów i mniejszości etnicznych, kształtującej wrażliwość kulturową przyszłych pielęgniarek. Jednakże, w większości ośrodków akademickich, takie programy kształcenia są ulokowane w sferze słusznych idei.

Reasumując, gorąco polecam lekturę monografii wieloautorskiej pt. Różnorodność kulturowa w opiece pielęgniarskiej, powstałej pod redakcją naukową dr Joanny Zalewskiej-Puchały i dr Anny Majdy. Gratuluję Autorkom i Redaktorkom szerokiego ujęcia zagadnienia popartego analizą trafnie dokonanego wyboru literatury przedmiotu.

Na zakończenie słowa uznania kieruję do Rady Małopolskiej Okręgowej Izby Pielęgniarek i Położnych za popieranie rozwoju pielęgniarstwa poprzez publikowanie mądrze dobranych pozycji książkowych, które stwarzają szansę pielęgniarkom i położnym na dostrzeżenie nowych horyzontów zawodowych. 